\title{
STRATEGI PEMASARAN EKSPOR PALA PADA PT. GUNUNG INTAN PERMATA MANADO
}

\author{
Goei Gracella Valencia \\ Ribka M. Kumaat \\ Grace A.J. Rumagit
}

\begin{abstract}
This study aims to analyze how marketing strategies implemented by PT. Gunung Intan Permata Manado in exporting the nutmeg products in order to compete with other companies. This study uses data obtanined from direct observation and interviews using questionnaires. Data analysis methods used were Matrix of Internal Factor Evaluation (IFE), Matrix of External Factor Evaluation (EFE), dan SWOT Analysis (Strengths, Weakness, Opportunities, Threats). The results showed that the marketing strategy of nutmeg export applied by PT. Gunung Intan Permata is an aggressive growth strategy (growth oriented strategy). This strategy is a profitable strategy, because the company has the power that can be used to achieve the opportunities that exist. This strategy can be implemented through several alternative strategies, namely maintaining product quality and further tightening quality control to keep nutmeg demand high and maintain product quality and corporate image to maintain good business relationships and customer loyalty.
\end{abstract}

Keyword: Marketing strategy, export, SWOT analysis, PT Gunung Intan Permata, Manado

\begin{abstract}
ABSTRAK
Penelitian ini bertujuan untuk menganalisis bagaimana strategi pemasaran yang diterapkan oleh PT. Gunung Intan Permata Manado.dalam mengekspor produk pala yang dihasilkan, agar dapat bersaing dengan perusahaan lain. Penelitian ini menggunakan data yang diperoleh dari pengamatan langsung dan wawancara menggunakan kuesioner. Metode analisis data yang digunakan yaitu Internal Factor Evaluation (IFE) Matrix. External Factor Evaluation (EFE) Matrix, dan Analisis SWOT (Strengths, Weakness, Opportunities, Threats). Hasil penelitian menunjukkan bahwa strategi pemasaran ekspor pala yang diterapkan oleh PT. Gunung Intan Permata adalah strategi pertumbuhan yang agresif (growth oriented strategy). Strategi ini merupakan strategi yang menguntungkan, karena perusahaan memiliki kekuatan yang dapat digunakan untuk mencapai peluang yang ada. Strategi ini dapat diimplementasikan melalui beberapa strategi alternatif, yaitu mempertahankan kualitas produk serta lebih memperketat pengendalian mutu untuk menjaga agar permintaan pala tetap tinggi dan menjaga kualitas produk serta citra perusahaan untuk mempertahankan hubungan bisnis yang baik dan keloyalan konsumen.
\end{abstract}

Kata kunci: strategi pemasaran, ekspor, analisis SWOT, PT Gunung Intan Permata, Manado 


\section{PENDAHULUAN}

\section{Latar Belakang}

Indonesia merupakan negara yang terkenal akan hasil pertanian. Negara-negara lain saling bersaing untuk mendapatkan hasil pertanian Indonesia. Hal tersebut dimanfaatkan untuk mendorong kegiatan ekspor di Indonesia yang sistem ekonominya tergantung pada perdagangan internasional atau perdagangan antar negara. Perdagangan internasional memiliki manfaat bagi suatu negara yang akan mendorong negara tersebut untuk memacu transaksi ekspor keluar negeri sehingga dapat meningkatkan pertumbuhan ekonomi dan pendapatan nasional. Saat ini perdagangan internasional di Indonesia sudah semakin berkembang. Salah satu aktivitas perekonomian yang tidak dapat dilepaskan dari perdagangan internasional adalah aktivitas aliran modal, baik yang sifatnya masuk maupun keluar, dari suatu negara. Ketika terjadi aktivitas perdagangan internasional berupa kegiatan ekspor dan impor maka besar kemungkinan terjadi perpindahan faktor-faktor produksi dari negara eksportir ke negara importir yang disebabkan oleh perbedaan biaya dalam proses perdagangan internasional (Salvatore dalam Safitriani, 2013).

Aktivitas ekspor adalah bentuk keterlibatan perusahaan dalam bisnis internasional yang paling sederhana. Perusahaan menggunakan kapasitas produksi domestik yang dimilikinya untuk produksi, distribusi, administrasi, dan mengalokasikan sejumlah tertentu produksi dalam negerinya untuk pasar luar negeri. Perusahaan membuat barang secara lokal dan mengirimkannya ke pasar internasional lewat udara, kapal, kereta api, truk, atau bahkan jaringan pipa melewati batas suatu negara (Kuncoro, 2001). Dengan adanya ekspor dapat memberikan beberapa keuntungan bagi suatu negara seperti peningkatan cadangan devisa, perluasan lapangan kerja, sebagai media untuk memperkenalkan produk dalam negeri dan keuntungan-keuntungan yang lainnya. Perusahaan dalam mengekspor produk-produk yang dihasilkan membutuhkan pemasaran yang tepat agar dapat bersaing dengan perusahaan lain. Hal ini dikarenakan semakin tingginya persaingan di dunia bisnis sehingga banyak perusahaan yang dituntut untuk mempertahankan produk perusahaan agar tetap diminati oleh konsumen.
Maka ilmu pemasaran (marketing) mendapat perhatian penuh dari para perusahaan.

Pemasaran adalah suatu proses kegiatan yang dipengaruhi oleh berbagai faktor sosial, budaya, politik, ekonomi dan manajerial. Akibat dari pengaruh berbagai faktor tersebut adalah masing-masing individu maupun kelompok mendapatkan kebutuhan dan keinginan dengan menciptakan, menawarkan, dan menukarkan produk yang memiliki nilai komoditas (Rangkuti, 2015). Dalam memasarkan produk dari suatu perusahaan perlu adanya strategi sehingga perusahaan tersebut bisa mendapatkan laba dan dapat bersaing dengan perusahaan lain yang berorientasi pada kegiatan atau produk yang serupa. Strategi pemasaran adalah logika pemasaran, dan berdasarkan itu, unit bisnis diharapkan untuk mencapai sasaransasaran pemasarannya. Strategi pemasaran perusahaan terdiri dari pengambilan keputusan tentang biaya pemasaran dari perusahaan, bauran pemasaran, dan alokasi pemasaran dalam hubungannya dengan keadaan lingkungan yang diharapkan dalam kondisi persaingan. Strategi pemasaran menyeluruh perusahaan tercermin dalam rencana strategi pemasaran perusahaan (Corporate Marketing Plan) yang disusun. Rencana strategi pemasaran perusahaan adalah suatu rencana pemasaran jangka panjang yang bersifat menyeluruh dan strategis, yang merumuskan berbagai strategi dan program pokok dibidang pemasaran perusahaan pada suatu jangka waktu tertentu dalam jangka panjang dimasa depan (Lubis, 2004). PT. Gunung Intan Permata merupakan salah satu perusahaan terbatas yang bergerak di bidang ekspor yang telah memperdagangkan pala sejak tahun 1994. PT. Gunung Intan Permata telah mengekspor produk mereka ke Italia, Belanda, Argentina, China, Vietnam, India, dan beberapa negara lain di Timur Tengah dan Asia. Berikut ini adalah Tabel kegiatan ekspor pala tahun 2013-2015.

\begin{tabular}{lccl}
\multicolumn{4}{c}{ Tabel 1. Kegiatan Ekspor Pala PT. Gunung Intan Permata Manado } \\
Tahun 2013-2015
\end{tabular}

Sumber: PT. Gunung Intan Permata Manado (2017) 
Tabel 1 menunjukan bahwa volume ekspor pala PT. Gunung Intan Permata Manado pada tahun 2013 sebesar 869,33 MTon (MetrikTon), sedangkan pada tahun 2014 dan 2015 volume ekspor pala cenderung meningkat sebesar 706,39 MTon. Berdasarkan pernyataan maka peneliti tertarik untuk meneliti tentang strategi pemasaran ekspor pala pada PT. Gunung Intan Permata.

\section{Rumusan Masalah}

Berdasarkan latar belakang tersebut maka yang menjadi permasalahan dalam penelitian ini adalah bagaimana strategi pemasaran ekspor pala pada PT. Gunung Intan Permata Manado.

\section{Tujuan Penelitian}

Adapun tujuan dari penelitian ini, yaitu untuk menganalisis strategi pemasaran ekspor pala yang harus diterapkan oleh PT. Gunung Intan Permata Manado.

\section{Manfaat Penelitian}

Manfaat dari penulisan penelitian ini adalah sebagai berikut:

1. Bagi perusahaan

Memberikan masukan ataupun saran mengenai perencanaan strategi pemasaran ekspor pala dari perusahaan.

2. Bagi penulis dan pembaca

Melatih cara berpikir serta diharapkan dapat bermanfaat untuk memperluas wawasan dan pengetahuan serta untuk mempelajari tentang strategi pemasaran.

\section{METODE PENELITIAN}

\section{Waktu dan Tempat Penelitian}

Penelitian ini dilaksanakan di kantor PT. Gunung Intan Permata Manado berlokasi di Jalan Arie Lasut No. 28 Kombos - Manado. Waktu penelitian ini direncanakan berlangsung selama 3 bulan, mulai dari bulan Maret hingga bulan Mei 2017.

\section{Metode Pengumpulan Data}

Data yang digunakan dalam penelitian ini adalah data primer dan data sekunder. Data primer diperoleh melalui pengamatan langsung (observasi) dan wawancara dengan menggunakan kuesioner. Responden terdiri dari pihak yang berkepentingan di perusahaan, yaitu manajer pemasaran dan administrasi, manajer keuangan, manajer sumber daya manusia, dan manajer produksi. Data sekunder diperoleh dari dokumen yang terdapat di dalam perusahaan, makalah-makalah seminar, literatur yang relevan dengan penelitian yang berasal dari perusahaan dan pihak-pihak yang terkait. Metode pengumpulan data yang digunakan dalam penelitian ini antara sebagai berikut:

a. Kuesioner

Metode pengumpulan data dengan memberikan daftar pertanyaan yang disampaikan kepada responden yang sudah dibuat terlebih dulu oleh peneliti untuk dijawab secara tertulis.

b. Dokumentasi

Adalah pengumpulan data dengan cara mencari catatan-catatan, dokumentasidokumentasi dan arsip-arsip dari pihak yang bersangkutan.

c. Wawancara

Wawancara adalah proses memperoleh keterangan atau data untuk tujuan penelitian dengan cara tanya jawab, sambil bertatap muka antara pewawancara dengan responden dengan menggunakan alat yang dinamakan pedoman wawancara.

\section{Konsep Pengukuran Variabel}

Adapun variabel yang diukur dalam penelitian ini yaitu sebagai berikut:

1) Mengidentifikasi indikator-indikator kekuatan (strength) yang terdapat di PT. Gunung Intan Permata Manado.

2) Mengidentifikasi indikator-indikator kelemahan (weakness) yang terdapat di PT. Gunung Intan Permata Manado.

3) Mengidentifikasi indikator-indikator peluang (opportunity) yang terdapat di PT. Gunung Intan Permata Manado.

4) Mengidentifikasi indikator-indikator ancaman (threath) yang terdapat di PT. Gunung Intan Permata Manado.

\section{Metode Analisis Data}

Metode analisis yang digunakan dalam penelitian ini adalah metode analisis SWOT dengan tahap-tahap sebagai berikut: 


\section{Tahap Masukan (Input Stage)}

\section{a. Identifikasi Faktor-Faktor Internal dan Eksternal Perusahaan}

Faktor-faktor strategi perusahaan terdiri dari dua faktor, yaitu faktor strategi internal dan faktor strategis eksternal. Faktor strategi internal terdiri dari 2 variabel, yaitu variabel kekuatan dan variabel kelemahan, dan faktor strategis eksternal yang terdiri dari 2 variabel, yaitu variabel peluang dan variabel ancaman. Identifikasi faktor-faktor internal dan eksternal dilakukan dengan FGD (Focus Group Discussion).

\section{b. Matriks IFE dan Matriks EFE}

Setelah faktor-faktor internal dan eksternal perusahaan diidentifikasi, langkah selanjutnya adalah mengevaluasi faktor-faktor internal dan eksternal dengan menggunakan matriks EFE dan matriks IFE. Berikut adalah cara-cara penentuan Faktor Strategi Eksternal:

a) Susunlah dalam kolom 1 (5 sampai dengan 10 peluang dan ancaman).

b) Beri bobot masing-masing faktor dalam kolom 2, mulai dari 1,0 (sangat penting) sampai dengan 0,0 (tidak penting). Faktorfaktor tersebut kemungkinan dapat memberikan dampak terhadap faktor strategis.

c) Hitung rating (dalam kolom 3) untuk masingmasing faktor dengan memberikan skala mulai dari 4 (outstanding) sampai dengan 1 (poor) berdasarkan pengaruh faktor tersebut terhadap kondisi perusahaan yang bersangkutan. Pemberian nilai rating untuk faktor peluang bersifat positif (peluang yang semakin besar diberi rating +4 , tetapi jika peluangnya kecil, diberi rating +1 ). Pemberian nilai rating ancaman adalah kebalikannya. Misalnya, jika nilai ancamannya sangat besar, ratingnya adalah 1 . Sebaliknya, jika nilai ancamannya sedikit ratingnya 4.

d) Kalikan bobot pada kolom 2 dengan rating pada kolom 3, untuk memperoleh faktor pembobotan dalam kolom 4. Hasilnya berupa skor pembobotan untuk masingmasing faktor yang nilainya bervariasi mulai dari 4, 0 (outstanding) sampai dengan 1,0 (poor).

e) Gunakan kolom 5 untuk memberikan komentar atau catatan mengapa faktor-faktor tertentu dipilih dan bagaimana skor pembobotannya dihitung. f) Jumlahkan skor pembobotan (pada kolom 4), untuk memperoleh total skor pembobotan bagi perusahaan yang bersangkutan. Nilai total ini menunjukkan bagaimana perusahaan tertentu bereaksi terhadap faktor-faktor strategis eksternalnya. Total skor ini dapat digunakan untuk membandingkan perusahaan ini dengan perusahaan lainnya dalam kelompok industri yang sama.

Selanjutnya berikut adalah cara-cara penentuan Faktor Strategi Internal:

a) Tentukan faktor-faktor yang menjadi kekuatan serta kelemahan perusahaan dalam kolom 1.

b) Beri bobot masing-masing faktor tersebut dengan skala mulai dari 1,0 (paling penting) sampai dengan 0,0 (tidak penting), berdasarkan pengaruh faktor-faktor tersebut terhadap posisi strategis perusahaan. (Semua bobot tersebut jumlahnya tidak boleh melebihi skor total 1,00).

c) Hitung rating (dalam kolom 3) untuk masingmasing faktor dengan memberikan skala mulai dari 4 (outstanding) sampai dengan 1 (poor), berdasarkan pengaruh faktor tersebut terhadap kondisi perusahaan yang bersangkutan. Variabel yang bersifat positif (semua variabel yang masuk kategori kekuatan) diberi nilai mulai dari +1 sampai dengan +4 (sangat baik) dengan membandingkannya dengan rata-rata industri atau dengan pesaing utama. Sedangkan variabel yang bersifat negatif, kebalikannya. Contohnya, jika kelemahan perusahaan besar sekali dibandingkan dengan rata-rata industri, nilainya adalah 1 , sedangkan jika kelemahan perusahan dibawah rata-rata industri, nilainya adalah 4.

d) Kalikan bobot pada kolom 2 dengan rating pada kolom 3, untuk memperoleh faktor pembobotan dalam kolom 4. Hasilnya berupa skor pembobotan untuk masingmasing faktor yang nilainya bervariasi mulai dari 4,0 (outstanding) sampai dengan 1,0 (poor).

e) Gunakan kolom 5 untuk memberikan komentar atau catatan mengapa faktor-faktor tertentu dipilih, dan bagaimana skor pembobotannya dihitung.

f) Jumlahkan skor pembobotan (pada kolom 4), untuk memperoleh total skor pembobotan bagi perusahaan yang bersangkutan. Nilai total ini menunjukkan bagaimana perusahaan 
tertentu bereaksi terhadap faktor-faktor strategis eksternalnya.

Untuk bobot setiap variabel diperoleh dengan menentukan nilai setiap variabel terhadap jumlah nilai keseluruhan variabel dengan menggunakan rumus (Kesatria, 2002):

Keterangan rumus:

$$
\alpha i=\frac{x i}{\sum_{i=1}^{n} x i}
$$

$$
\begin{aligned}
\alpha i & =\text { bobot variabel ke-i } \\
x i & =\text { nilai variabel ke-i } \\
i & =1,2,3, \ldots . . \\
\mathrm{n} & =\text { jumlah variabel }
\end{aligned}
$$

\section{Tahap Pencocokan (Matching Stage)}

Penentuan posisi perusahaan dilakukan dengan cara memadukan variabel kekuatan, kelemahan, peluang dan ancaman yang dimiliki perusahaan sehingga dapat ditentukan titik koordinat dalam diagram SWOT. Berikut merupakan gambar diagram analisis SWOT:

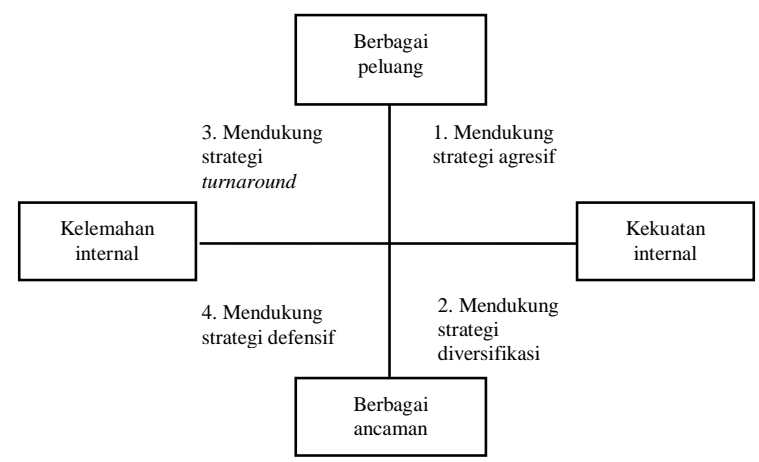

Sumber: Rangkuti, 2015

Gambar 1. Diagram Analisis SWOT

Keterangan Gambar 1:

Kuadran I: ini merupakan situasi yang sangat menguntungkan. Perusahaan tersebut memiliki peluang dan kekuatan sehingga dapat memanfaatkan peluang yang ada. Strategi yang harus diterapkan dalam kondisi ini adalah mendukung kebijakan pertumbuhan yang agresif (growth oriented strategy).

Kuadran II: meskipun menghadapi berbagai ancaman, perusahaan ini masih memiliki kekuatan dari segi internal.

Kuadran III: perusahaan menghadapi peluang pasar yang sangat besar, tetapi di lain pihak, ia menghadapi beberapa kendala atau kelemahan internal.
Kuadran IV: ini merupakan situasi yang sangat tidak menguntungkan, perusahaan tersebut menghadapi berbagai ancaman dan kelemahan internal.

\section{Tahap Keputusan (Decision Stage)}

Setelah mengetahui posisi perusahaan,

\begin{tabular}{|c|c|c|}
\hline EFAS & $\begin{array}{c}\text { Strengths } \\
\text { (Kekuatan) } \\
\text { Tentukan 5-10 faktor } \\
\text { kekuatan internal }\end{array}$ & $\begin{array}{c}\text { Weakness } \\
\text { (Kelemahan) } \\
\text { Tentukan 5-10 faktor } \\
\text { kelemahan internal }\end{array}$ \\
\hline $\begin{array}{l}\text { Opportunity } \\
\text { (Peluang) } \\
\text { Tentukan 5-10 } \\
\text { faktor peluang } \\
\text { eksternal }\end{array}$ & \begin{tabular}{l}
\multicolumn{2}{c}{ Strategi SO } \\
Ciptakan strategi \\
yang menggunakan \\
kekuatan untuk \\
memanfaatkan \\
peluang
\end{tabular} & \begin{tabular}{lr}
\multicolumn{3}{c}{ Strategi WO } \\
Ciptakan strategi yang \\
meminimalkan kelemahan \\
untuk memanfaatkan \\
peluang
\end{tabular} \\
\hline $\begin{array}{c}\text { Treaths } \\
\text { (Ancaman) } \\
\text { Tentukan 5-10 } \\
\text { faktor ancaman } \\
\text { eksternal }\end{array}$ & \begin{tabular}{l}
\multicolumn{2}{c}{ Strategi ST } \\
Ciptakan strategi \\
yang menggunakan \\
kekuatan untuk \\
mengatasi ancaman \\
\end{tabular} & $\begin{array}{l}\text { Strategi WT } \\
\text { Ciptakan strategi yang } \\
\text { meminimalkan kelemahan } \\
\text { dan menghindari ancaman }\end{array}$ \\
\hline
\end{tabular}
langkah selanjutnya adalah menentukan alternatif strategi pemasaran dengan menggunakan matriks SWOT. Berikut adalah Tabel matriks SWOT:

Tabel 2. Matriks SWOT

Dalam matriks SWOT akan menghasilkan penggabungan faktor-faktor strategis perusahaan yang telah teridentifikasi. Keempat alternatif strategis antara lain:

1. Strategi SO (Strenght-Opportunity)

Strategi ini dibuat berdasarkan jalan pikiran perusahaan, yaitu dengan memanfaatkan seluruh kekuatan untuk merebut dan memanfaatkan peluang sebesar-besarnya.

2. Strategi ST (Strenght-Threats)

Strategi ini digunakan dengan menggunakan kekuatan yang dimiliki perusahaan untuk mengatasi ancaman.

3. Strategi WO (Weakness-Opportunity)

Strategi ini diterapkan berdasarkan pemanfaatan peluang yang ada dengan cara meminimalkan kelemahan yang ada.

4. Strategi WT (Weakness-Threats)

Strategi ini didasarkan pada kegiatan yang bersifat defensif dan berusaha meminimalkan kelemahan yang ada serta menghindari ancaman.

\section{HASIL DAN PEMBAHASAN}

\section{Sejarah Singkat PT. Gunung Intan Permata}

PT. Gunung Intan Permata adalah perusaaan dagang, lebih khusus ekspor hasil bumi. Dahulunya perusahaan ini berbentuk 
kemitraan (Commanditaire Vennootschap atau CV) dan sudah berdiri sejak tahun 1994. Pada tahun 2010 berubah status menjadi Perseroan Terbatas (PT). Perusahaan ini dikelola oleh para pengusaha yang sudah sangat berpengalaman di bidang perdagangan khususnya hasil bumi (pala, bunga pala, daging pala, cengkeh, batang cengkeh, dan juga kulit pala) selama lebih dari 20 tahun. PT. Gunung Intan Permata membeli pala dari daerah Kepulauan SITARO, khususnya Siau dan pulau-pulau sekitarnya. Pulau Siau dikatakan memiliki kualitas pala yang terbaik dan sangat terkenal di seluruh dunia. PT. Gunung Intan Permata telah berhasil mengekspor pala ke beberapa negara tujuan seperti, Italia, Belanda, Argentina, Jepang, China, Vietnam, India, dan beberapa negara lain di Timur Tengah dan Asia. Jenis barang-barang yang diekspor di antaranya pala (nutmeg), bunga pala (mace), daging pala (nutmeg pulp), cengkeh (cloves), batang cengkeh (cloves stems), dan juga kulit pala (nutmeg shells). Perusahaan juga memiliki hubungan bisnis yang baik dengan beberapa prosesor rempah-rempah sebagai pembeli reguler. Dalam menjalankan aktivitas, perusahaan ini didukung sejumlah tenaga kerja yang berasal dari penduduk setempat dengan menyerap tenaga kerja sekitar 200 orang dengan didominasi oleh lebih dari $70 \%$ pekerja wanita. Pemberdayaan sumber daya manusia dari daerah setempat memberikan kontribusi tersendiri bagi perputaran ekonomi di daerah ini.

PT. Gunung Intan Permata ditugaskan sebagai pilot project oleh Uni Eropa (UE)Indonesia untuk mendukung perdagangan Program tim TSP (Trade Support Programme) II dalam proyek percontohan untuk menjaga kualitas pala yang di ekspor ke Uni Eropa pada periode 2011-2015. Diharapkan bahwa proyek percontohan ini secara efektif akan memberikan kontribusi untuk mempertahankan produksi pala berkualitas tinggi di Indonesia, meningkatkan peluang di pasar Uni Eropa dan juga akan melindungi dan meningkatkan kesejahteraan kurang lebih lima puluh ribu keluarga petani di wilayah kepulauan Indonesia yang terlibat langsung dalam industri pala.

Visi dan Misi PT. Gunung Intan Permata

Visi : "Menjadi pengekspor hasil bumi yang handal dalam mengelola sumber daya alam yang ada dalam negeri"
Misi : "Berusaha untuk membawa produk lokal dengan pengetahuan lokal dan usaha sebagai salah satu bahan terbaik di dunia untuk membawa kembali kejayaan rempah-rempah dari Indonesia".

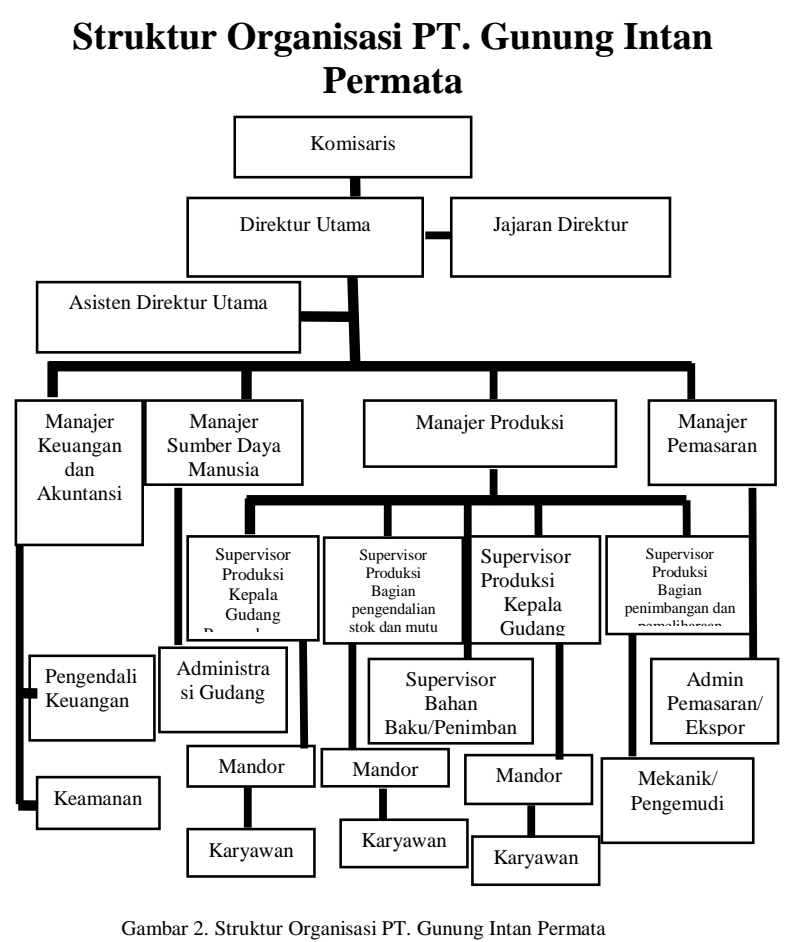

\section{Bauran Pemasaran PT. Gunung Intan Permata}

\section{Produk (Product)}

Produk merupakan salah satu bagian dari bauran pemasaran yang dihasilkan maupun ditawarkan oleh perusahaan kepada konsumen. Produk pala yang diekspor PT. Gunung Intan Permata di antaranya terdiri dari pala (nutmeg), bunga pala (mace), dan daging pala (nutmeg pulp).

\section{a. Pala (Nutmeg)}

Pala adalah biji kernel yang ada di dalam buah pada pohon pala. Pohon pala adalah pohon cemara yang menghasilkan tidak hanya satu melainkan dua rempah-rempah yaitu pala dan fuli. Pala terbagi dalam beberapa jenis antara lain, Nutmegs ABCD, Nutmegs80/85, Nutmegs100/110, Nutmegs Shrivels, Nutmegs BWPRecondition, dan Nutmeg shell.

b. Bunga Pala (Mace)

Bunga pala merupakan cangkang pala. Bunga pala berupa bentuk jaring berwarna merah. Ketika bunga pala kering, warnanya akan 
perlahan berubah menjadi oranye, dan akan menjadi kuning jika disimpan untuk waktu yang lama. Bunga pala dapat digunakan sebagai bahan penyedap. Bunga pala ini terbagi menjadi 2 jenis yaitu, Mace Whole II dan Mace Broken II.

c. Daging Pala (Nutmeg Pulp)

Daging pala berasal dari buah pala yang menutupi fuli dan biji pala. Kebanyakan daging pala dianggap hanya memiliki sedikit maupun tidak bernilai, karena ketika panen pala, buah pala sering dibuang. Buah pala mengandung kelembaban tinggi dan ketika kering, kehilangan sebagian besar berat. Buah pala juga dikatakan mengandung miristisin yang lebih sedikit dibandingkan dengan biji pala. Buah pala biasanya digunakan untuk membuat selai dan permen. Daging pala kering digunakan untuk dicampur dengan rempah-rempah lainnya.

\section{Harga (Price)}

Harga merupakan nilai yang ada pada suatu produk yang ditawarkan oleh perusahaan.

Tabel 3. Harga Produk Pala PT. Gunung Intan Permata Tahun 2013-2015

\begin{tabular}{cll}
\hline No. & Produk Pala & Harga (USD/Ton) \\
\hline 1. & Nutmegs ABCD & $12.750-13.000$ \\
2. & Nutmegs Shrivels & $11.800-13.000$ \\
3. & Nutmegs BWP & $7.000-8.000$ \\
4. & Nutmegs Pulp & $2.500-2.700$ \\
5. & Mace Whole II & $12.700-13.500$ \\
6. & Mace Broken II & $13.000-13.500$ \\
7. & Nutmegs BWP & $11.000-11.500$ \\
& $\begin{array}{l}\text { Recondition } \\
\text { 8. }\end{array}$ & Nutmegs ABCD \\
100/110 $12.000-14.000$ \\
9. & $\begin{array}{l}\text { Nutmegs ABCD } \\
\text { 80/85 } 12.500-15.000\end{array}$ \\
10. & Nutmegs Shell & $350-500$ \\
\hline
\end{tabular}

Sumber: PT. Gunung Intan Permata (2017)

Harga yang ditawarkan oleh PT. Gunung Intan Permata beragam sesuai dengan produk pala yang diekspor. Tabel 3 menunjukan bahwa produk pala yang paling mahal adalah Nutmegs ABCD 80/85 dengan harga US\$ 12.500 - 15.000 sedangkan produk pala yang paling murah adalah Nutmegs Shell dengan harga US\$ $350-500$.

\section{Tempat atau Distribusi (Place)}

Tempat atau Distribusi mencakup mulai dari sistem transportasi dari perusahaan dalam mengekspor barang, penyimpanan barang, dan pemilihan saluran distribusi. PT. Gunung Intan Permata mengekspor pala ke beberapa negara tujuan seperti, Italia, Belanda, Argentina, Jepang, China, Vietnam, India, dan beberapa negara lain di Timur Tengah dan Asia. PT. Gunung Intan Permata membeli pala dari daerah Kepulauan SITARO, khususnya Siau dan pulau-pulau sekitarnya. Pala yang dibeli dari daerah tersebut kemudian disortir kembali di perusahaan sehingga menghasilkan kualitas yang lebih baik dari sebelumnya. Setelah pala yang disortir sesuai dengan standar mutu yang ditetapkan, pala dikemas dan dikirim kepada pelanggan.

\section{Promosi (Promotion)}

Promosi adalah suatu kegiatan yang dilakukan perusahaan agar produk yang ditawarkan oleh perusahaan dapat dikenal oleh masyarakat luas. Promosi yang dilakukan oleh PT. Gunung Intan Permata yaitu dengan penawaran kepada calon pembeli dengan cara email, telepon, faximile, maupun pemasaran secara langsung.

\section{Orang atau Sumber Daya Manusia (People)}

Dalam menjalankan aktivitas, PT. Gunung Intan Permata didukung oleh sejumlah tenaga kerja yang berasal dari penduduk setempat dengan menyerap tenaga kerja sekitar 200 orang dengan didominasi oleh lebih dari $70 \%$ pekerja wanita. Pemberdayaan sumber daya manusia dari daerah setempat memberikan kontribusi tersendiri bagi perputaran ekonomi di daerah ini.

\section{Sarana Fisik (Physical Evidence)}

PT. Gunung Intan Permata memiliki gedung kantor, gudang penyimpanan barang, penyortiran barang dan transportasi yang digunakan dalam kegiatan ekspor.

\section{Proses (Process)}

Proses dalam PT. Gunung Intan Permata berawal dari proses bongkar muatan pala yang kemudian ditimbang dan diuji mutunya. Setelah uji mutu dinyatakan lulus maka pala tersebut disimpan. Proses selanjutnya adalah pala yang disimpan kemudian diayak dan dipecah untuk dipisahkan mutunya. Setelah pala melalui proses pisah mutu, dilakukan tes afla-toxin. Jika pala tidak memebuhi syarat maka akan diproses kembali, tetapi apabila pala memenuhi syarat, langkah selanjutnya adalah pengemasan dan fumigasi kemudian siap untuk dikirim. Proses pengiriman pala ke negara tujuan berlangsung selama 3 bulan. 


\section{Identifikasi Lingkungan Internal dan \\ Eksternal PT. Gunung Intan Permata}

Faktor lingkungan perusahaan terbagi menjadi dua, yaitu faktor lingkungan internal dan faktor lingkungan eksternal.Faktor lingkungan internal terdiri dari variabel kekuatan dan kelemahan, sedangkan faktor lingkungan eksternal terdiri dari variabel peluang dan ancaman.

\section{Identifikasi Lingkungan Internal PT. Gunung Intan Permata}

Identifikasi faktor internal perusahaan merupakan lingkungan bisnis yang terdiri dari kekuatan dan kelemahan yang dimiliki oleh perusahaan. Berikut adalah faktor-faktor kekuatan dan kelemahan yang dimiliki oleh PT. Gunung Intan Permata, antara lain:

1) Kekuatan (Strength)

a) Produk yang ditawarkan perusahaan berkualitas.

b) Kualitas pengiriman (distribusi) yang baik.

c) Pengelola perusahaan yang berpengalaman.

d) Citra perusahaan yang baik dikalangan konsumen.

e) Pengendalian mutu yang ketat.

f) Pemberian pelatihan oleh tenaga ahli perorangan.

2) Kelemahan (Weakness)

a) Kurangnya penciptaan produk yang baru.

b) Adanya biaya ekstra untuk menghasilkan pala yang berkualitas.

c) Kurangnya sarana promosi.

\section{Identifikasi Lingkungan Eksternal PT. Gunung Intan Permata}

Identifikasi faktor lingkungan eksternal perusahaan meliputi faktor-faktor peluang yang harus dimanfaatkan oleh perusahaan dan faktorfaktor ancaman yang harus dihadapi oleh perusahaan. Berikut adalah faktor-faktor peluang dan ancaman yang dimiliki oleh PT. Gunung Intan Permata, antara lain:

1) Peluang (Opportunity)

a) Hubungan bisnis yang baik dengan konsumen.

b) Konsumen yang loyal.

c) Bantuan fasilitas teknologi dari pemerintah.

d) Kerjasama dengan supplier yang berpengalaman.

e) Suplai bahan baku yang berkualitas.

f) Daya saing di pasar bahan baku.

g) Permintaan pala yang tinggi.

2) Ancaman (Threat) a) Banyaknya pesaing dalam bidang yang sama

b) Terkadang adanya penolakan permintaan dari konsumen.

c) Tidak ada jaminan keberlangsungan bantuan dari pemerintah.

\section{Perumusan Alternatif Strategi}

Setelah mengidentifikasi faktor-faktor lingkungan internal dan eksternal perusahaan selanjutnya adalah perumusan alternatif strategi. Perumusan alternatif strategi terdiri dari tahap masukan, tahap pencocokan dan tahap keputusan.

\section{Tahap Masukan (Input Stage)}

Tahap masukan terdiri dari evaluasi faktor-faktor internal dan eksternal yang dimiliki oleh perusahaan.

\section{a. Evaluasi Faktor Internal (IFE)}

Evaluasi faktor internal merupakan hasil dari identifikasi faktor internal seperti kekuatan dan kelemahan yang berpengaruh terhadap PT. Gunung Intan Permata. Penentuan bobot dan rating diperoleh dari empat orang responden dengan cara mengisi kuisioner, sedangkan skor diperoleh dengan mengalikan bobot dan rating.

Tabel 4. Matriks IFE PT. Gunung Intan Permata

\begin{tabular}{|c|c|c|c|c|}
\hline No & Kekuatan & Bobot & Rating & Skor \\
\hline 1 & $\begin{array}{l}\text { Produk yang ditawarkan } \\
\text { perusahaan berkualitas }\end{array}$ & 0.141 & 4.00 & 0.564 \\
\hline 2 & $\begin{array}{l}\text { Kualitas pengiriman } \\
\text { (distribusi) yang baik }\end{array}$ & 0.127 & 3.75 & 0.476 \\
\hline 3 & $\begin{array}{l}\text { Pengelola perusahaan yang } \\
\text { berpengalaman }\end{array}$ & 0.141 & 4.00 & 0.564 \\
\hline 4 & $\begin{array}{l}\text { Citra perusahaan yang baik } \\
\text { dikalangan konsumen }\end{array}$ & 0.134 & 3.75 & 0.503 \\
\hline 5 & $\begin{array}{l}\text { Pengendalian mutu yang } \\
\text { ketat }\end{array}$ & 0.141 & 4.00 & 0.564 \\
\hline \multirow[t]{2}{*}{6} & $\begin{array}{l}\text { Pemberian pelatihan oleh } \\
\text { tenaga ahli perorangan }\end{array}$ & 0.120 & 3.25 & 0.390 \\
\hline & Jumlah Kekuatan & & & 3.061 \\
\hline No & Kelemahan & Bobot & Rating & Skor \\
\hline 1 & $\begin{array}{l}\text { Kurangnya penciptaan } \\
\text { produk yang baru }\end{array}$ & 0.070 & 1.75 & 0.123 \\
\hline 2 & $\begin{array}{l}\text { Adanya biaya ekstra untuk } \\
\text { menghasilkan pala yang } \\
\text { berkualitas }\end{array}$ & 0.056 & 1.50 & 0.084 \\
\hline \multirow[t]{3}{*}{3} & Kurangnya sarana promosi & 0.070 & 2.00 & 0.140 \\
\hline & Jumlah Kelemahan & & & 0.347 \\
\hline & $\begin{array}{l}\text { Total Kekuatan dan } \\
\text { Kelemahan }\end{array}$ & 1.000 & & 3.408 \\
\hline & uatan - Kelen & -0.3 & .714 & \\
\hline
\end{tabular}

Sumber: Data Primer (2017)

Tabel 4 menunjukan bahwa produk yang ditawarkan perusahaan berkualitas, pengelola perusahaan yang berpengalaman dan pengendalian mutu yang ketat merupakan kekuatan utama dari PT. Gunung Intan Permata. 
Ketiga indikator tersebut memiliki nilai skor 0,564 yang berarti kekuatan paling penting dalam perusahaan. Sedangkan adanya biaya ekstra untuk menghasilkan pala yang berkualitas merupakan kelemahan utama dari PT. Gunung Intan Permata dengan nilai skor 0,084 .

\section{b. Evaluasi Faktor Eksternal (EFE)}

Evaluasi faktor eksternal merupakan hasil dari identifikasi faktor eksternal seperti peluang dan ancaman yang berpengaruh terhadap PT. Gunung Intan Permata. Penentuan bobot dan rating diperoleh dari empat orang responden dengan cara mengisi kuisioner, sedangkan skor diperoleh dengan mengalikan bobot dan rating.

Tabel 5. Matriks EFE PT. Gunung Intan Permata

\begin{tabular}{|c|c|c|c|c|}
\hline No & Peluang & Bobot & Rating & Skor \\
\hline 1 & $\begin{array}{l}\text { Hubungan bisnis yang baik } \\
\text { dengan konsumen }\end{array}$ & 0.132 & 4.00 & 0.528 \\
\hline 2 & Konsumen yang loyal & 0.118 & 3.50 & 0.413 \\
\hline 3 & $\begin{array}{l}\text { Bantuan fasilitas teknologi } \\
\text { dari pemerintah }\end{array}$ & 0.092 & 3.00 & 0.276 \\
\hline 4 & $\begin{array}{l}\text { Kerjasama dengan supplier } \\
\text { yang berpengalaman }\end{array}$ & 0.125 & 3.75 & 0.469 \\
\hline 5 & $\begin{array}{l}\text { Suplai bahan baku yang } \\
\text { berkualitas }\end{array}$ & 0.132 & 4.00 & 0.528 \\
\hline 6 & $\begin{array}{l}\text { Daya saing di pasar bahan } \\
\text { baku }\end{array}$ & 0.099 & 3.00 & 0.297 \\
\hline \multirow[t]{3}{*}{7} & Permintaan pala yang tinggi & 0.118 & 3.25 & 0.384 \\
\hline & Jumlah Peluang & & & 2.895 \\
\hline & Ancaman & & & \\
\hline 1 & $\begin{array}{l}\text { Banyaknya pesaing dalam } \\
\text { bidang yang sama }\end{array}$ & 0.053 & 1.25 & 0.066 \\
\hline 2 & $\begin{array}{l}\text { Terkadang adanya penolakan } \\
\text { permintaan dari konsumen }\end{array}$ & 0.059 & 1.50 & 0.089 \\
\hline \multirow[t]{3}{*}{3} & $\begin{array}{l}\text { Tidak ada jaminan } \\
\text { keberlangsungan bantuan dari } \\
\text { pemerintah }\end{array}$ & 0.072 & 2.00 & 0.144 \\
\hline & Jumlah Ancaman & & & 0.299 \\
\hline & Total Peluang dan Ancaman & 1.000 & & 3.194 \\
\hline Sk & eluang - Ancaman $=2.895-$ & $9=2$ & & \\
\hline
\end{tabular}

Tabel 5 menunjukan bahwa hubungan bisnis yang baik dengan konsumen dan suplai bahan baku yang berkualitas menjadi peluang utama dari PT. Gunung Intan Permata karena memiliki skor 0,528. Kerjasama dengan supplier yang berpengalaman juga menjadi peluang bagi perusahaan karena memiliki skor 0,469 . Adapun faktor eksternal yang menjadi ancaman paling besar bagi PT. Gunung Intan Permata yaitu banyaknya pesaing dalam bidang yang sama dengan skor 0,066 .

\section{Tahap Pencocokan (Matching Stage)}

Tahap pencocokan (matching stage) adalah tahap untuk merumuskan strategi berdasarkan hasil dari analisis dan identifikasi kondisi lingkungan internal dan eksternal perusahaan. Tahap pencocokan ini terdiri dari penentuan posisi perusahaan dengan menggunakan diagram SWOT. Diagram SWOT merupakan diagram yang digunakan untuk menentukan posisi perusahaan dengan cara memadukan kekuatan (strength), kelemahan (weakness), peluang (opportunities) dan ancaman (threat) sehingga dapat ditentukan titik koordinat.

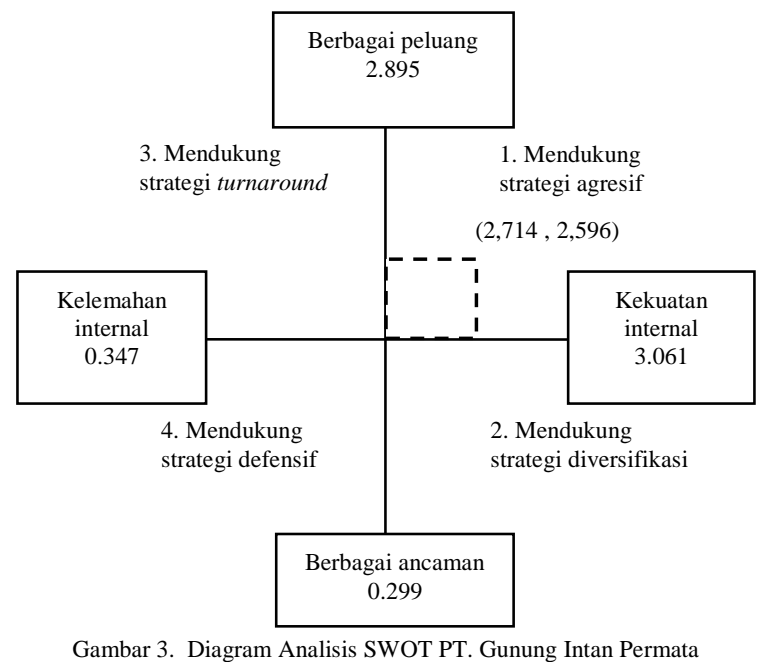

Gambar 3 menunjukan titik koordinat $(2,714,2,596)$ yang diperoleh berada pada kuadran I, yaitu posisi perusahaan yang mendukung kebijakan pertumbuhan yang agresif (growth oriented strategy). Posisi ini merupakan situasi yang mengutungkan bagi perusahaan karena memiliki kekuatan dan peluang yang besar. Perusahaan dapat menggunakan kekuatan yang ada untuk mencapai peluang.

\section{Tahap Keputusan (Decision Stage)}

Tahap keputusan (decision stage) merupakan tahap ketiga dari perumusan alternatif strategi. Untuk merumuskan alternatif strategi digunakan matriks SWOT dengan mengkombinasikan faktor-faktor internal dan eksternal perusahaan. Matriks SWOT merupakan matriks yang digunakan 
untuk mengkombinasikan kekuatan, kelemahan, peluang dan ancaman yang menghasilkan beberapa alternatif strategi. Berikut adalah Matriks SWOT PT. Gunung Intan Permata:

Tabel 6. Matriks SWOT PT. Gunung Intan Permata

\begin{tabular}{|c|c|c|}
\hline Eksternal & \begin{tabular}{ll}
\multicolumn{2}{l}{ Strengths (S) } \\
1. & $\begin{array}{l}\text { Produk yang } \\
\text { ditawarkan perusahaan }\end{array}$ \\
berkualitas. (S1) \\
2. & $\begin{array}{l}\text { Kualitas pengiriman } \\
\text { (distribusi) yang baik. }\end{array}$ \\
(S2) \\
3.
\end{tabular} & $\begin{array}{l}\text { Weaknesses (W) } \\
\text { 1. Kurangnya penciptaan } \\
\text { produk yang baru. (W1) } \\
\text { 2. Adanya biaya ekstra } \\
\text { untuk menghasilkan pala } \\
\text { yang berkualitas. (W2) } \\
\text { 3. Kurangnya sarana } \\
\text { promosi (W3) }\end{array}$ \\
\hline $\begin{array}{l}\text { Opportunities (O) } \\
\text { 1. Hubungan bisnis } \\
\text { yang baik dengan } \\
\text { konsumen. (O1) } \\
\text { 2. Konsumen yang } \\
\text { loyal. (O2) } \\
\text { 3. Bantuan fasilitas } \\
\text { teknologi dari } \\
\text { pemerintah. (O3) } \\
\text { 4. Kerjasama dengan } \\
\text { supplier yang } \\
\text { berpengalaman. } \\
\text { (O4). Suplai bahan baku } \\
\text { 5. Sang berkualitas. } \\
\text { yang } \\
\text { (O5) Daya saing di } \\
\text { 6. Daya bahan baku. } \\
\text { pasar ba } \\
\text { (O6) } \\
\text { 7. Permintaan pala } \\
\text { yang tinggi. (O7) }\end{array}$ & $\begin{array}{l}\text { Strategi S-O } \\
\text { 1. Mempertahankan } \\
\text { kualitas produk dan } \\
\text { lebih memperketat } \\
\text { pengendalian mutu } \\
\text { untuk menjaga } \\
\text { permintaan pala agar } \\
\text { tetap tinggi (S1, S5 - } \\
\text { O7) } \\
\text { 2. Menjaga kualitas } \\
\text { produk serta citra } \\
\text { perusahaan untuk } \\
\text { mempertahankan } \\
\text { hubungan bisnis yang } \\
\text { baik dan keloyalan } \\
\text { konsumen (S1, S4 - } \\
\text { O1, O2) }\end{array}$ & $\begin{array}{l}\text { Strategi W-O } \\
\text { 1. Mencegah penggunaan } \\
\text { biaya ekstra dalam } \\
\text { menghasilkan pala yang } \\
\text { berkualitas dengan } \\
\text { mempererat kerjasama } \\
\text { dengan supplier yang } \\
\text { berpengalaman (W2 - } \\
\text { O4) }\end{array}$ \\
\hline $\begin{array}{l}\text { Threats }(\mathbf{T}) \\
\text { 1. Banyaknya } \\
\text { pesaing dalam } \\
\text { bidang yang sama } \\
\text { (T1) } \\
\text { 2. Terkadang adanya } \\
\text { penolakan } \\
\text { permintaan dari } \\
\text { konsumen. (T2) } \\
\text { 3. Tidak ada jaminan } \\
\text { keberlangsungan } \\
\text { bantuan dari } \\
\text { pemerintah. (T3) } \\
\end{array}$ & $\begin{array}{l}\text { Strategi S-T } \\
\text { 1. Mempertahankan dan } \\
\text { meningkatkan kualitas } \\
\text { produk untuk lebih } \\
\text { dapat bersaing dengan } \\
\text { perusahaan yang ada } \\
\text { (S1-T1) } \\
\text { 2. Lebih memperketat } \\
\text { pengendalian mutu } \\
\text { untuk mencegah } \\
\text { terjadinya penolakan } \\
\text { permintaan (S5-T2) }\end{array}$ & $\begin{array}{l}\text { Strategi W-T } \\
\text { 1. Meningkatkan promosi } \\
\text { untuk mencegah } \\
\text { terjadinya penolakan } \\
\text { permintaan pala dari } \\
\text { konsumen (W3 - T2) }\end{array}$ \\
\hline
\end{tabular}

Alternatif strategi yang dihasilkan antara lain strategi S-O, strategi S-T, strategi W-O dan strategi W-T.

\section{a. Strategi $\mathbf{S - O}$}

Strategi S-O merupakan strategi yang diterapkan berdasarkan pemanfaatan kekuatan yang dimiliki untuk merebut dan memanfaatkan peluang sebesar-besarnya. Berdasarkan kekuatan yang dimiliki dan peluang yang akan dihadapi oleh PT. Gunung Intan Permata dapat dirumuskan alternatif strategi yaitu mempertahankan kualitas produk serta lebih memperketat pengendalian mutu untuk menjaga agar permintaan pala tetap tinggi (S1, S5 - O7) dan menjaga kualitas produk serta citra perusahaan untuk mempertahankan hubungan bisnis yang baik dan keloyalan konsumen (S1, S4 - O1, O2).

\section{b. Strategi S-T}

Strategi S-T merupakan strategi yang diterapkan dengan menggunakan kekuatan yang dimiliki perusahaan untuk mengatasi ancaman yang ada. Berdasarkan kekuatan yang dimiliki dan ancaman yang akan dihadapi PT. Gunung Intan Permata dapat dirumuskan alternatif strategi yaitu mempertahankan dan meningkatkan kualitas produk untuk lebih dapat bersaing dengan perusahaan yang ada (S1 - T1) dan lebih memperketat pengendalian mutu untuk mencegah terjadinya penolakan permintaan (S5 - T2).

\section{c. Strategi W-O}

Strategi W-O merupakan strategi yang diterapkan berdasarkan pemanfaatan peluang yang ada dengan cara meminimalkan kelemahan yang ada. Berdasarkan kelemahan yang dimiliki dan peluang yang ada pada PT. Gunung Intan Permata dapat dirumuskan strategi, yaitu mencegah penggunaan biaya ekstra dalam menghasilkan pala yang berkualitas dengan mempererat kerjasama dengan supplier yang berpengalaman (W2-O4).

\section{d. Strategi W-T}

Strategi W-T merupakan strategi yang diterapkan pada kegiatan yang bersifat defensif dan berusaha meminimalkan kelemahan yang ada serta menghindari ancaman. Berdasarkan kelemahan yang dimiliki dan ancaman yang dihadapi PT. Gunung Intan Permata dapat dirumuskan alternatif strategi yaitu meningkatkan promosi untuk mencegah terjadinya penolakan permintaan pala dari konsumen (W3 - T2).

\section{KESIMPULAN DAN SARAN}

\section{Kesimpulan}

Berdasarkan hasil penelitian dan pembahasan, maka strategi pemasaran ekspor pala yang harus diterapkan oleh PT. Gunung Intan Permata adalah strategi pertumbuhan yang agresif (growth oriented strategy). Strategi ini merupakan strategi yang menguntungkan, karena perusahaan memiliki kekuatan yang dapat digunakan untuk mencapai peluang yang 
ada. Strategi ini dapat diimplementasikan melalui beberapa strategi alternatif, yaitu: Mempertahankan kualitas produk serta lebih memperketat pengendalian mutu untuk menjaga agar permintaan pala tetap tinggi dan menjaga kualitas produk serta citra perusahaan untuk mempertahankan hubungan bisnis yang baik dan keloyalan konsumen.

\section{Saran}

Hal-hal yang dapat disarankan untuk PT. Gunung Intan Permata adalah mempertahankan kualitas produk serta lebih memperketat pengendalian mutu untuk menjaga agar permintaan pala tetap tinggi, menjaga kualitas produk serta citra perusahaan untuk mempertahankan hubungan bisnis yang baik dan keloyalan konsumen, mempertahankan dan meningkatkan kualitas produk untuk lebih dapat bersaing dengan perusahaan yang ada, lebih memperketat pengendalian mutu untuk mencegah terjadinya penolakan permintaan, mencegah penggunaan biaya ekstra dalam menghasilkan pala yang berkualitas dengan mempererat kerjasama dengan supplier yang berpengalaman, dan meningkatkan promosi untuk mencegah terjadinya penolakan permintaan pala dari konsumen.

\section{DAFTAR PUSTAKA}

Ahyani, Y.M. 2009. Strategi Pemasaran Ekspor Buah-Buahan Pada PT. Agroindo Usaha Jaya. Institut Pertanian Bogor.

Assauri, S. 2014. Manajemen Pemasaran: Dasar, Konsep, dan Strategi. PT. RajaGrafindo Persada. Jakarta.

Erisandi, T. 2016. Pengaruh Bauran Pemasaran Terhadap Keputusan Penggunaan Produk Tabungan Simpedes Pada PT. Bank Rakyat Indonesia Unit Baraka Kabupaten Enrekang. Universitas Hasanuddin. Makassar.
Hasan, F.D. 2012. Pengaruh Bauran Pemasaran Jasa Terhadap Loyalitas Nasabah Pada PT. Bank Rakyat Indonesia (Persero) Tbk, Cabang Achmad Yani. Universitas Hasanuddin. Makassar.

Kesatria, T.F. 2002. Analisis Strategi Pemasaran Ekspor Teh Hitam Pada Kantor Pemasaran Bersama (KPB) PT Perkebunan Nusantara.Intitut Pertanian Bogor.

Kotler, P. dan Keller, K.L. 2009.Manajemen Pemasaran Edisi 13 Jilid 1.Erlangga. Jakarta.

Kuncoro, M. 2001. Manajemen Keuangan Internasional: Pengantar Ekonomi Dan Bisnis Global Edisi II. BPFE.Yogyakarta.

Lubis, A.N. 2004. Strategi Pemasaran Dalam Persaingan Bisnis. Universitas Sumatera Utara. Medan.

Purwanto, I. 2008. Manajemen Strategi. CV.YRAMA WIDYA. Bandung.

Putra, D.A. 2013. Analisis Faktor-Faktor Yang Mempengaruhi Ekspor Tembakau Indonesia Ke Jerman.Universitas Negeri Semarang.

Rangkuti, F. 2015. Analisis SWOT: Teknik Membedah Kasus Bisnis. Gramedia Pustaka Utama. Jakarta.

Robiulina, S. 2011. Kajian Pengaruh Proses Perendaman Dan Lama Penyimpanan Biji Pala (Myristica fragrans HOUTT) Terhadap Rendemen Dan Kualitas Minyak Pala. Institut Pertanian Bogor.

Safitriani, S. 2013. Perdagangan Internasional (Ekspor Dan Impor) Dan Foreign Direct Investment (FDI) Di Indonesia Periode 1996-2012. Sekolah Tinggi Ilmu Statistik (STIS). Jakarta. 
Soedjamiko, R.W. 2000. Analisa Strategi Pemasaran Ekspor Produk Tekstil Di PT. Primissima. Universitas Diponegoro. Semarang.

Sukirno, S. 2013. Makroekonomi Teori Pengantar Edisi III. PT. RajaGrafindo Persada. Jakarta.

Sukoco, H. 2012. Analisis Pengaruh Ekuitas Merek Produk Herbal Albiruni Terhadap Keputusan Konsumen. Universitas Sebelas Maret. Surakarta.
Sumarlina, E. 2002.Analisis Strategi Pemasaran Ekspor Mebel Rotan Pada CV Dimo Putera Jaya.Institut Pertanian Bogor.

Yanuaria, L.W. 2012.Strategi PT Kereta Api Indonesia (KAI) Dalam Meningkatkan Pelayanan Transportasi Kereta Api. Universitas Negeri Yogyakarta.

Yunus, E. 2016. Manajemen Strategis. CV.ANDI OFFSET. Yogyakarta. 